\title{
Analisis Biaya Dan Efisiensi Produksi Dalam Ekonomi Islam
}

\author{
M. Muhazil Amshari \\ Pasca Sarjana Institut Agama Islam Negeri (IAIN) Parepare \\ mohamedmohazil05@gmail.com
}

\begin{abstract}
Abstrak
Produsen secara rasional akan berproduksi dengan biaya minimum. Karenanya, produsen harus menganalisis seberapa mampu dalam mengubah jumlah input yang akan mempengaruhi skala produksi. Dalam menganalisis biaya produksi, analisis biaya produksi dibedakan menjadi dua, yaitu biaya jangka pendek dan biaya jangka panjang. Dalam sistem bagi hasil, karena tidak adanya beban bunga, maka biaya produksi tidak akan berubah, yang berubah adalah total pendapatan yang bergantung pada nisbah bagi hasil yang disepakati. Dengan membandingkan antara sitem bunga dan bagi hasil, pada tingkat produksi dengan jumlah yang sama, biaya total yang digunakan pada sistem bunga lebih besar dibandingkan pada sistem bagi hasil demikian halnya pada jumlah biaya yang sama, tingkat produksi pada sistem bagi hasil lebih besar dibandingkan pada sistem bunga. Hal ini berarti sistem bagi hasil lebih efisien.
\end{abstract}

Kata Kunci: Efisiensi Produksi, Analisis Biaya, Bagi Hasil

\section{Pendahuluan}

Manusia sebagai khalifah di bumi telah diberi amanah untuk memanfaatkan berbagai sumber daya yang ada. Implementasi dari pemanfaatannya yaitu dengan melakukan kegiatan produksi. Dalam literatur konvensional teori produksi ditujukan untuk untuk memberikan pemahaman tentang perilaku perusahaan dalam membeli dan menggunakan masukan (input) untuk produksi dan menjual keluaran (output). Dalam kegiatan produksi dibutuhkan faktor-faktor produksi, yaitu alat atau sarana untuk melakukan proses produksi.

Produksi yang dihasilkan dengan menggunakan faktor alam disebut dengan produksi alami. Sedangkan jika produksi dilakukan dengan 
memanipulasi faktor-faktor produksi disebut produksi rekayasa. ${ }^{1}$ Produksi yang bersifat alami efisiensi maupun efektivitasnya tidak dapat dikontrol sebab bersifat eksternal. Kelebihan dan kekurangan produksi alami merupakan suatu hal yang harus diterima oleh pengguna. Sementara itu, produksi rekayasa adalah produksi yang bersifat internal sehingga efektivitas dan efisiensi produksi dapat diatur.

Secara garis besar perilaku produsen ada dua, yaitu: 1) maksimalisasi profit dan 2) minimalisasi biaya. Dalam melakukan perilaku tersebut produsen membutuhkan cara paling efisien dengan memilih jenis sumber modal. Produsen dapat memilih sumber modal apa yang cocok untuk mengoptimalkan output, seperti qard (pinjaman tanpa kompensasi), syirkah (sebagian menggunakan modal dari pihak lain), mudharabah (bagi hasil atas kesepakatan bersama), atau meminjam uang ke bank yang berbasis bunga.

Setiap sumber modal yang berbeda dapat memberikan efek yang berbeda pula atas output yang dihasilkan. Oleh karena itu, produsen perlu untuk melakukan analisis biaya sebagai salah satu cara untuk mengestimasi seberapa besar produksi yang akan dihasilkan. Artikel ini, akan membahas bagaimana dampak yang diperoleh ketika prosuden menggunakan sistem bunga atau sistem bagi hasil dalam melakukan analisis biayadan pandangan Islam mengenai maksimalisasi produksi dan minimalisasi biaya.

\section{Analisis Biaya Dalam Ekonomi Islam}

Perbedaan ekonomi Islam dengan ekonomi konvensional adalah pada filsosofi ekonomi yang dianutnya dan bukan pada ilmu ekonominya. Filosofi ekonomi memberikan ruh pemikiran dengan nilai-nilai Islam dan batasanbatasan syariah, sedangkan ilmu ekonomi berisikan perangkat-perangkat analisis ekonomi yang dapat digunakan. Oleh karenanya faktor produksi

${ }^{1}$ Iskandar Putong, Ekonomi Mikro dan Makro, (Jakarta: Ghalia Indonesia, 2002). 
dalam ekonomi Islam tidak berbeda dengan faktor produksi ekonomi konvensional. ${ }^{2}$

1. Fungsi Biaya

Definisi biaya dalam ilmu ekonomi adalah pengorbanan untuk menghasikan sesuatu, baik yang berwujud uang maupun bukan ${ }^{3}$. Analisis biaya berhubungan antara biaya dengan kegiatan produksi. Karenanya dapat diartikan bahwa biaya produksi adalah semua pengeluaran yang dilakukan oleh perusahaan untuk memperoleh faktor-faktor produksi dan bahan-bahan mentah yang akan digunakan untuk menciptakan barangbarang yang diproduksi oleh produsen.

Analisis yang fundamental dalam menerangkan biaya adalah fungsi hubungan antara biaya produksi dengan tingkat output yang akan dicapai dalam satu periode. ${ }^{4}$ Faktor produksi adalah biaya yang dinilai dengan uang sehingga total biaya mencerminkan jumlah faktor produksi yang dikorbankan. Pembahasan teori biaya menggunakan dua asumsi, yaitu ${ }^{5}$ :

a) Perusahaan bergerak pada pasar persaingan sempurna. Harga output ditentukan pasar.

b) Faktor produksi yang digunakan adalah barang dan modal tenaga kerja. Dalam jangka pendek hanya tenaga kerja yang bersifat variabel.

Produsen secara rasional akan berproduksi dengan biaya minimum. Karenanya, produsen harus menganalisis seberapa mampu dalam mengubah jumlah input yang akan mempengaruhi skala produksi. Dalam menganalisis biaya produksi, analisis biaya produksi dibedakan menjadi dua, yaitu:

a. Biaya Jangka Pendek

2 Muhammad, Ekonomi Mikro Islam, (Yogyakarta: BPFE, 2016), h. 262

${ }^{3}$ M Umar Burhan, Konsep Dasar Teori Ekonomi Mikro, (Malang: Badan Penerbit Fakultas Ekonomi Universitas Brawijaya, 2006), h. 157

${ }^{4}$ Adiwarman A. Karim, Ekonomi Mikro Islami, (Jakarta: The International Institute of Islamic Thought, 2002), h. 138.

${ }^{5}$ Masyhuri, Ekonomi Mikro, (Malang: UIN-Malang Press, 2007), h. 173. 
Jangka pendek adalah periode waktu dimana produsen tidak dapat merubah kuantitas input yang digunakan, bisa ukuran hari, minggu, bulan dan sebagainya. ${ }^{6}$ Dalam jangka pendek, konsep biaya biaya terdiri atas :

1) Biaya Tetap Total (Total Fixed Cost / TFC)

Yaitu biaya yang jumlahnya tidak tergantung atas besar kecilnya kuantitas produksi yang dikeuarkan apabila produsen dalam waktu sementara produksi dihentikan, maka biaya tetap ini harus dibayar dalam jumlah yang sama. ${ }^{7}$ Contohnya adalah pembelian gedung, mesin, sewa gedung, pajak, dan lain-lain.

2) Biaya Variabel Total (Total Variable Cost / TVC)

Yaitu biaya yang jumlahnya berubah-ubah sesuai dengan perubahan kuantitas produk yang dihasilkan makin besar kuantitas produksi maka makin besar produk yang dihasilkan. ${ }^{8}$ Contohnya adalah pembelian bahan baku, biaya tenaga kerja, dan sebagainya.

3) Biaya Total (Total Cost / TC)

Yaitu jumlah dari biaya tetap total dan biaya variabel total. ${ }^{9}$

4) Biaya Marjinal (Marginal Cost / MC)

Yaitu berapa besar perubahan biaya total yang dikeluarkan perusahaan apabila jumlah output yang diproduksi berubah satu unit. ${ }^{10}$ Secara matematis ditulis $: \mathrm{MC}=\frac{\Delta C}{\Delta Q}$.

5) Biaya Tetap Rata-rata (Average Fixed Cost /AFC)

Yaitu biaya tetap yang harus dikeluarkan setiap unit output. Secara matematis ditulis : $\mathrm{AFC}=\frac{T F C}{Q}$.

${ }^{6}$ Suryawati, Teori Ekonomi Mikro, (Yogyakarta: AMP YKPN, t.t), h. 83.

${ }^{7}$ Masyhuri, Ekonomi..., h. 173.

8 Masyhuri, Ekonomi...,h. 175.

${ }^{9}$ Suryawati, Teori..., h. 83.

${ }^{10}$ Sri Adiningsih dan Y.B Kadarusman, Teori Ekonomi Mikro, (Yogyakarta: BPFEYogyakarta, 2008), h. 41. 
6) Biaya Variabel Rata-rata (Average Variable Cost / AVC)

Yaitu biaya variabel yang dibebankan kepada kepada setiap unit output. Secara matematis ditulis : $\mathrm{AVC}=\frac{T V C}{Q}$.

7) Biaya Rata-rata (Average Cost / AC)

Yaitu biaya diproduksi yang diperhitungkan untuk setiap unit output. Secara matematis ditulis : $\mathrm{AC}=\frac{T C}{Q}$.

b. Biaya Jangka Panjang

Dalam jangka panjang, memungkinkan produsen untuk mengubah jumlah semua input yang digunakan sehingga tidak ada input tetap. ${ }^{11}$ Produsen dapat menambah semua faktor produksi yang digunakannya. Sehingga tidak ada perbedaan antara biaya tetap dan biaya variabel. Oleh karena itu, produsen bisa memilih kombinasi input yang paling efisien untuk mempeoleh biaya terendah.

Untuk memproduksi suatu produk tertentu, dibutuhkan biaya tetap (FC) dan biaya total (TC). Produk yang dihasilkan akan dijual untuk mendapatkan penerimaan, maka akan ditemukan total penerimaan penjualan produk atau total revenue (TR). Hubungan antara FC, TC dan TR dapat digambarkan dalam grafik berikut: ${ }^{12}$

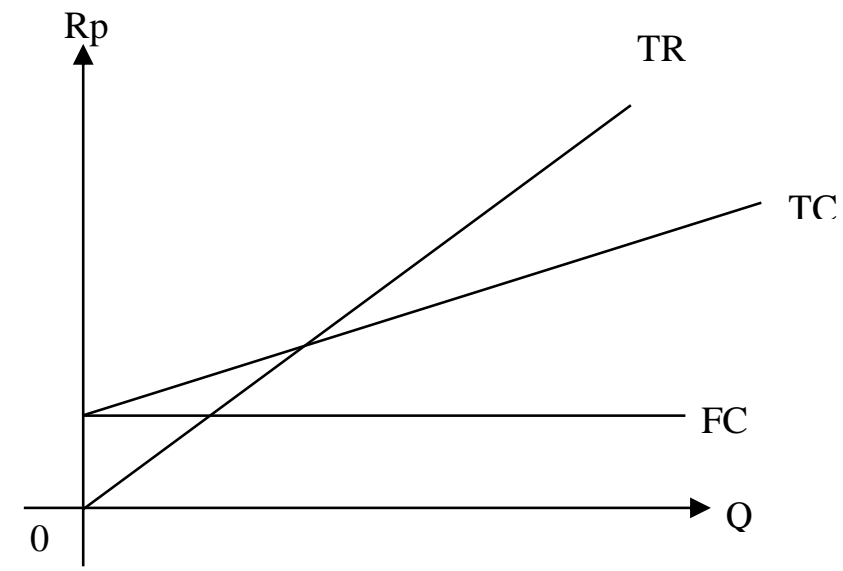

Gambar 1

11 Suryawati, Teori ..., h. 89.

12 Muhammad, Ekonomi..., h. 263. 
2. Dampak Sistem Bunga vs Bagi Hasil dalam Analisis Biaya

Karakteristik sistem bunga dalam analisis biaya produksi adalah biaya bunga yang harus dibayarkan produsen bersifat tetap. ${ }^{13}$ Oleh karena itu, biaya bunga merupakan bagian dari fixed cost, maka biaya bunga akan meningkatkan total biaya. Adanya beban bunga yang harus dibayar produsen sebagai biaya tetap pada akhirnya akan meningkatkan biaya total dari TC ke TC . Naiknya biaya total akan mendorong BEP dari suatu Q $\left(Q_{1}\right)$ ke $Q$ berikutnya $\left(Q_{2}\right)$. Grafiknya dapat dilihat pada gambar 2 .

Dengan adanya beban bunga, besarnya biaya tetap naik, dengan demikian biaya keseluruhan juga naik. Hal ini menyebabkan Q bergeser dari $\mathrm{Q}_{1}$ ke $\mathrm{Q}_{2}$. Total penerimaan dalam system bunga sama sekali tidak terpengaruh $\left(\mathrm{TR}=\mathrm{TR}_{\mathrm{i}}\right)$.

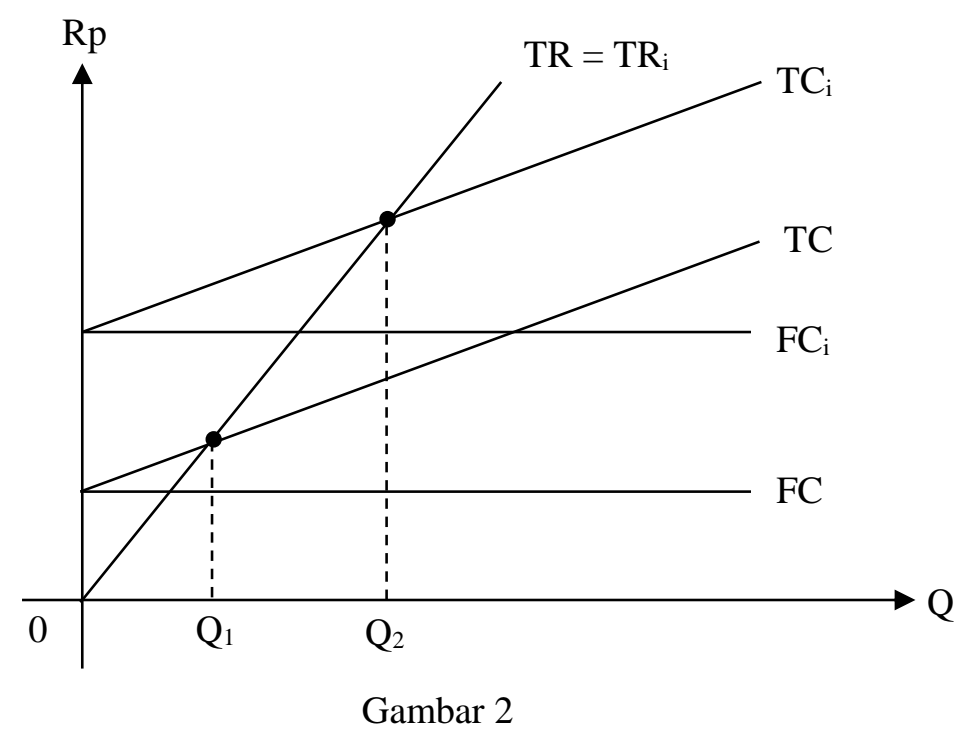

Jika pada sistem bunga, biaya total mengalami perubahan, berbeda halnya dengan sistem bagi hasil. Dalam sistem bagi hasil, yang berubah adalah kurva total penerimaan (TR). Kurva ini akan bergerak berputar searah jarum jam dengan titik 0 sebagai porosnya. Besar kecilnya putaran

${ }^{13}$ Adiwarman A. Karim, Ekonomi..., h.139. 
tersebut tergantung pada nisbah bagi hasil yang disepakati. Kurva TR ini akan berputar sehingga dapat mendekati sumbu horizontal.

Bagi hasil ekonomi Islam dapat berupa revenue sharing dan profit sharing. Pada sistem revenue sharing seluruh biaya ditanggung oleh pemilik modal. Sementara pengelola tidak menanggung biaya produksi. Oleh karena itu, yang dibagihasilkan adalah penerimaan (revenue). BEP terjadi ketika kurva TR berpotongan dengan kurva TC $(\mathrm{TR}=\mathrm{TC})$. Bergesernya kurva total penerimaan dari TR menuju ke TRrs, maka titik BEP yang tadinya berada pada $Q$ akan begeser ke $Q_{\text {rs. Grafiknya dapat }}$ dilihat pada gambar 3 .

Sistem revenue sharing memiliki persamaan dan perbedaan dengan sistem bunga. Persamaannya terletak pada bergesernya $Q$ ke $Q_{i} / Q_{r s}$ $\left(Q_{i}>Q\right.$ dan $\left.Q_{r s}>Q\right)$ pada posisinya di BEP. Sedangkan perbedaannnya adalah jika pada sistem bunga yang bergerak adalah kurva biaya tetap (FC) dan kurva biaya total (TC), pada sistem revenue sharing kurva yang bergeser adalah kurva total penerimaan (TR). Apakah $\mathrm{Q}_{\mathrm{i}}>\mathrm{Q}_{\mathrm{rs}}$ atau $\mathrm{Q}_{\mathrm{i}}<\mathrm{Q}_{\mathrm{rs}}$ atau $Q_{i}=Q_{r s}$ akan tergantung oleh seberapa besar bunga dibandingkan dengan besar nisbah bagi hasil.

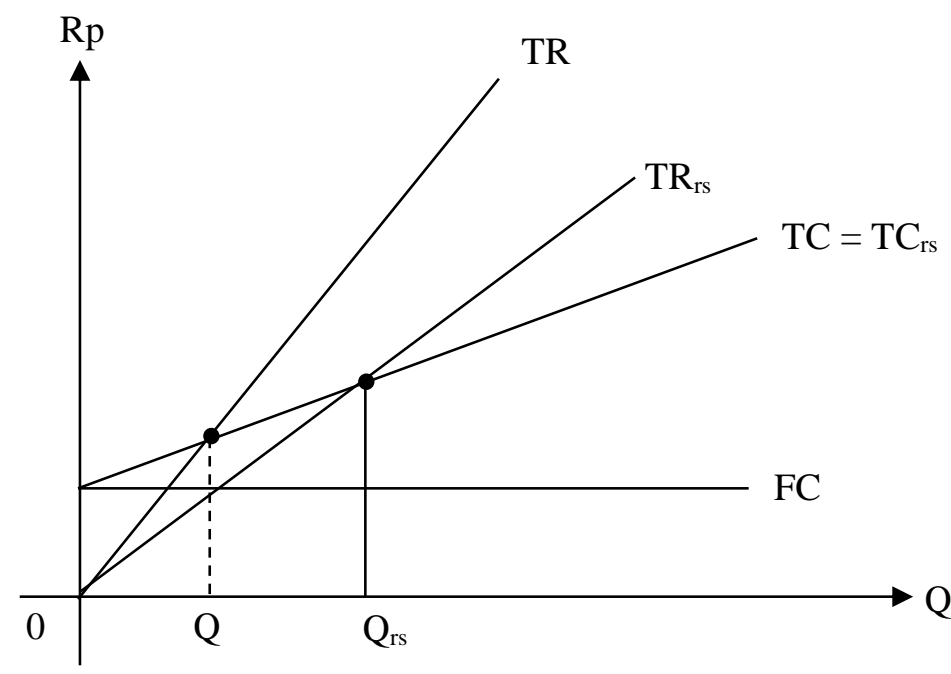

Gambar 3 
Selanjutnya pada sistem profit sahing seluruh biaya ditanggung oleh pengelola modal. Sementara pemilik modal tidak menanggung biaya produksi. Oleh karena itu, yang dibagihasilkan adalah keuntungan (profit). Kurva TR pada sistem profit sharing akan berputar dengan poros BEP (BEP sebagai tanda mulai terjadinya keuntungan). Tingkat produksi sebelum BEP tercapai $(\mathrm{Q}<\mathrm{Qps})$ adalah keadaan di mana total biaya lebih besar dibandingkan dengan total penerimaan (TC > TR) begitupun sebaliknya. Putaran $\mathrm{TR}_{\mathrm{ps}}$ akan terjadi hanya berkisar antara kurva TR dengan TC, yaitu ruang yang menggambarkan besarnya keuntungan. Grafik dapat dilihat pada gambar 4.

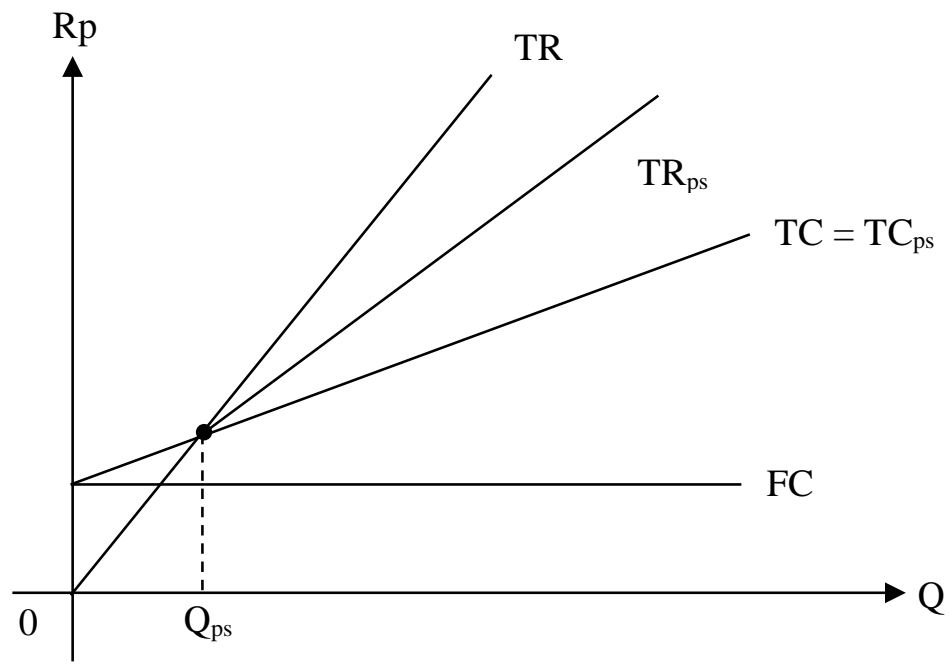

Gambar 4

Untuk lebih memperjelas perbandingan di antara ketiga sistem tersebut, akan coba kita terapkan pada contoh kasus berikut:

- Kapasitas produksi beras pada lahan seluas 1 hektar adalah 10 ton. Untuk memproduksi beras sebanyak itu diperlukan total biaya tetap sebesar total Rp.4 juta dan total biaya variabel Rp. 50 juta. Harga jual beras di pasaran adalah Rp. 12.000/kg. 
- Dari data di atas akan dibandingkan analisa biaya dengan kondisi:

a) Sumber modal sendiri

b) Sumber modal dari pinjaman dengan sistem bunga $20 \%$

c) Sumber modal dari pinjaman dengan revenue sharing (nisbah 40:60)

d) Sumber modal dari pinjaman dengan profit sharing (nisbah 90:10)

a) Sumber modal sendiri

Dari data sebelumnya dapat diketahui:

$\mathrm{TQ}=10 \mathrm{ton}=10.000 \mathrm{~kg}$

$\mathrm{TFC}=$ Rp. 4.000 .000

TVC $=$ Rp. 50.000.0000; maka AVC = Rp. 5.000/kg

$\mathrm{P}=$ Rp. $12.000 / \mathrm{kg}$.

Untuk mencapai BEP, TR = TC maka:

$\mathrm{P} \times \mathrm{Q}=\mathrm{TFC}+\mathrm{TVC}$

$\mathrm{P} \times \mathrm{Q}=\mathrm{TFC}+(\mathrm{AVR} \times \mathrm{Q})$

$12.000 \times \mathrm{Q}=4.000 .000+(5.000 \times \mathrm{Q})$

$12.000 \mathrm{Q}=4.000 .000+5.000 \mathrm{Q}$

$7.000 \mathrm{Q}=4.000 .000$

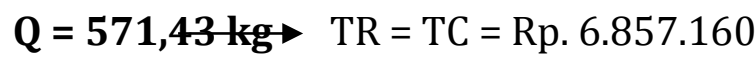

Jadi, untuk mencapai BEP beras yang harus diproduksi sebesar $571,43 \mathrm{~kg}$ dengan biaya total sebesar Rp. 6.857.160.

b) Sumber modal dari pinjaman dengan sistem bunga $20 \%$

$\mathrm{TQ}=10$ ton $=10.000 \mathrm{~kg}$

$\mathrm{TFC}=4.000 .000+20 \% \times 54.000 .000$

$=$ Rp. 14.800 .000

TVC = Rp. 50.000.0000; maka AVC = Rp. $5.000 / \mathrm{kg}$

$\mathrm{P}=$ Rp. $12.000 / \mathrm{kg}$.

Untuk mencapai BEP, TR = TC maka: 
$\mathrm{P} \times \mathrm{Q}=\mathrm{TFC}+\mathrm{TVC}$

$\mathrm{P} \times \mathrm{Q}=\mathrm{TFC}+(\mathrm{AVR} \times \mathrm{Q})$

$12.000 \times \mathrm{Q}=14.800 .000+(5.000 \times \mathrm{Q})$

$12.000 \mathrm{Q}=14.8000 .000+5.000 \mathrm{Q}$

$7.000 \mathrm{Q}=14.800 .000$

$\mathrm{Q}=2.114,29 \mathrm{~kg}$ $\mathrm{TR}=\mathrm{TC}=\mathrm{Rp} .25 .371 .480$

Jadi, untuk mencapai BEP beras yang harus diproduksi sebesar 2.114,29 kg dengan biaya total sebesar Rp. 25.371.480.

c) Sumber modal dari pinjaman dengan revenue sharing (nisbah 40:60)

$\mathrm{TQ}=10 \mathrm{ton}=10.000 \mathrm{~kg}$

$\mathrm{TFC}=4.000 .000$

TVC = Rp. 50.000.0000; maka AVC = Rp. 5.000/kg

$\mathrm{P}=$ Rp. $12.000 / \mathrm{kg}$.

Karena biaya produksi ditanggung oleh pemilik modal, maka BEP akan dilijat dari perspektif pemilik modal. Untuk mencapai BEP, TR $=$ TC maka:

$\mathrm{P} \times \mathrm{Q}=\mathrm{TFC}+\mathrm{TVC}$

$\mathrm{P} \times \mathrm{Q}=\mathrm{TFC}+(\mathrm{AVR} \times \mathrm{Q})$

$(60 \% \times 12.000) \times Q=4.00 .000+(5.000 \times Q)$

$7.200 \mathrm{Q}=4.000 .000+5.000 \mathrm{Q}$

$2.200 \mathrm{Q}=4.000 .000$

$\mathrm{Q}=1.818,18 \mathrm{~kg} \longrightarrow \mathrm{TR}=\mathrm{TC}=\mathrm{Rp} .21 .818 .160$.

Jadi, untuk mencapai BEP beras yang harus diproduksi sebesar 1.818,18 kg dengan biaya total sebesar Rp. 21.818.160.

d) Sumber modal dari pinjaman dengan profit sharing (nisbah 90:10) BEP akan terjadi sama dengan kondisi jika menggunakan modal sendiri, karena profit sharing hanya akan terjadi jika terjadi BEP. 


$$
\mathrm{Q}=571,43 \mathrm{~kg} \longrightarrow \mathrm{TR}=\mathrm{TC}=\mathrm{Rp} \cdot 6.857 .160 .
$$

Sekarang akan kita bandingkan analisis biaya ketiga sistem tersebut dengan memperhatikan grafik pada gambar 5. Pada grafik tersebut terlihat nilai $\mathrm{Q}_{\mathrm{ps}}<\mathrm{Q}_{\mathrm{rs}}<\mathrm{Q}_{\mathrm{i}}$. Karena profit sharing hanya akan setelah pada BEP, maka nilai $Q_{p s}$ akan selalu lebih kecil dari $Q_{\text {rs }}$ dan $\mathrm{Q}_{1}$ tanpa terpengaruh oleh besar kecilnya nisbah bagi hasil dibanding bunga. Sedangkan nilai $Q_{r s}$ bisa saja lebih lebih besar dari $Q_{i}$ tergantung seberapa besar bunga dibandingkan dengan nisbah bagi hasil. Jika besarnya bunga diturunkan, maka bisa saja terjadi $\mathrm{Q}_{\mathrm{i}}<\mathrm{Q}_{\mathrm{rs}}$.

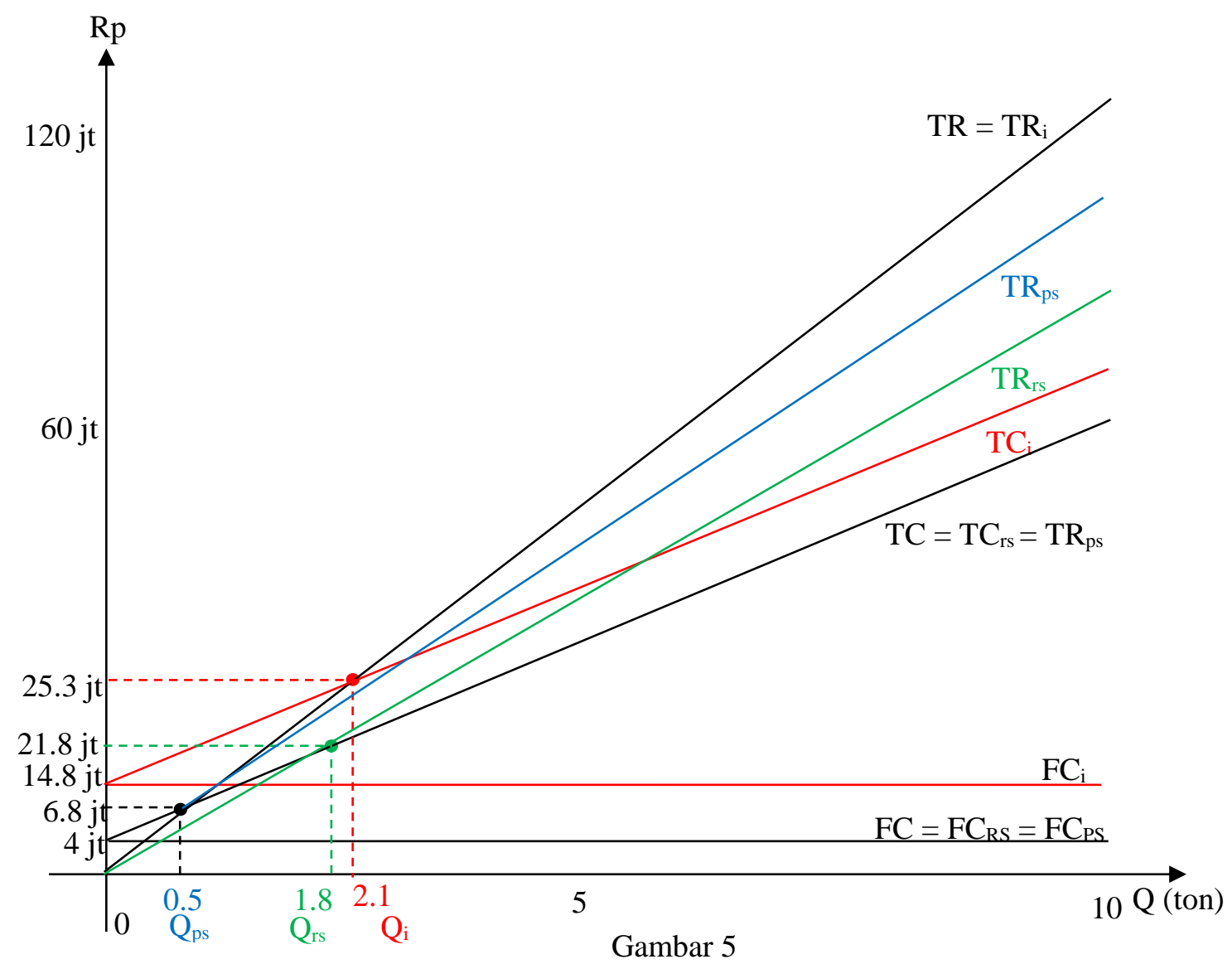




\section{Efisiensi Biaya dalam Produksi}

Efisiensi produksi menurut kriteria ekonomi harus memenuhi salah satu dari dua kriteria berikut:

1. Minimalisasi biaya untuk memproduksi jumlah yang sama.

Efisiensi produksi dilakukan dengan minimalisasi biaya produksi dalam jumlah yang sama dilakukan dengan membandingkan antara biaya total sistem bunga dengan biaya total bagi hasil. Biaya total sistem bunga akan lebih tinggi daripada biaya total bagi hasil. Biaya total bagi hasil digambarkan oleh TC, sedangkan biaya total sistem bunga digambarkan oleh $\mathrm{TC}_{\mathrm{i}}$.

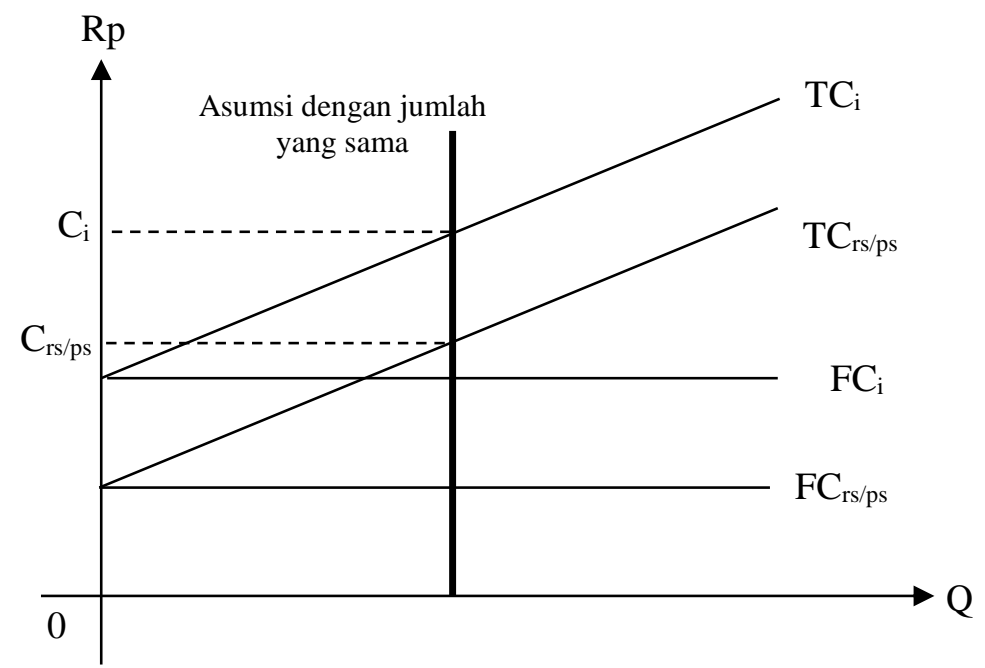

Gambar 6

Pertama menentukan titik dimana saja pada sumbu X sebagai titik yang menggambarkan tingkat produksi yang sama ( $Q$ yang sama). Kemudian membuat garis vertikal sampai memotong $\mathrm{TC}$ dan $\mathrm{TC}_{\mathrm{i}}$ dari titik yang telah ditentukan. Selanjutnya membuat garis horizontal pada sumbu $\mathrm{Y}$ untuk masing-masing perpotongan antara garis vertikal $\mathrm{TC}_{\mathrm{i}}$ dan $\mathrm{TC}_{\mathrm{rs} / \mathrm{ps}}$. Sehingga untuk tingkat produksi yang sama (Q yang sama), biaya total 
sistem bagi hasil ( $\mathrm{TC}_{\mathrm{rs} / \mathrm{ps}}$ ) akan selalu lebih kecil dibandingkan biaya total dengan sitem bunga $\left(\mathrm{TC}_{\mathrm{i}}\right)$, sebab keberadaan bunga menjadi beban bagi produsen. Karena biaya tetap (FC) naik, maka akan meningkatkan biaya total (TC). Jadi dapat disimpulkan bahwa pada kriteria ini, produksi dengan sistem bagi hasil (revenue sharing dan profit sharing) lebih efisien dibandingkan dengan menggunakan sistem bunga

2. Optimalisasi produksi dengan jumlah biaya yang sama. ${ }^{14}$

Optimalisasi produksi dengan jumlah biaya yang sama atau dengan kata lain disebut maksimalisasi, dengan menggunakan total biaya. Kurva total biaya sistem bunga dibandingkan dengan kurva total biaya sistem bagi hasil.

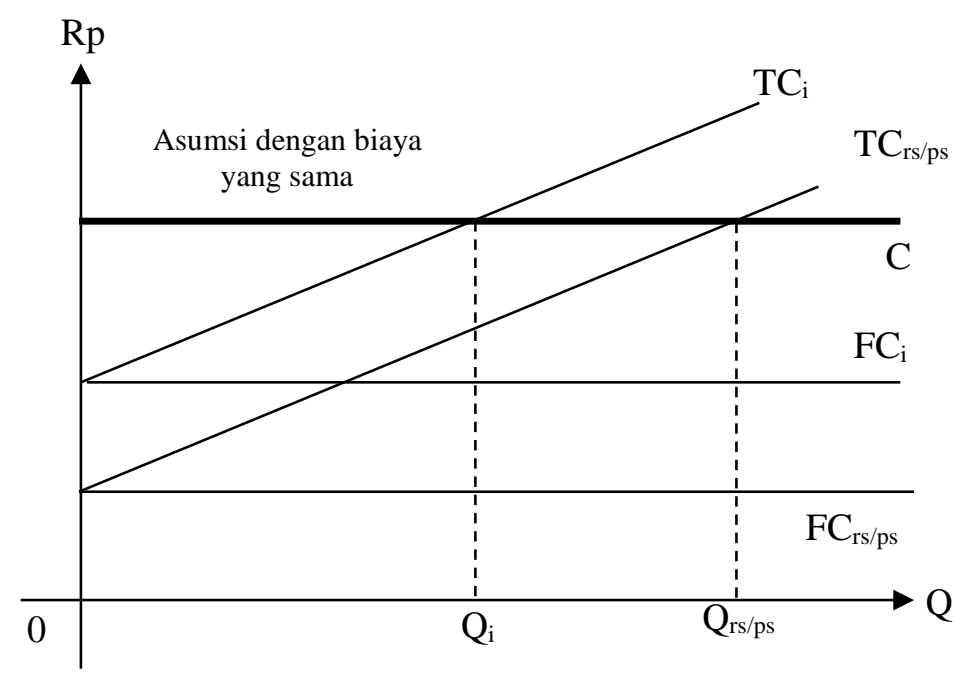

Gambar 7

Pertama menentukan titik di mana saja pada sumbu Y sebagai titik yang menggambarkan biaya total yang sama (TC yang sama), tentunya menentukan titik yang di atas garis $\mathrm{FC}_{\mathrm{i}}$. Kemudian membuat garis

${ }^{14}$ Muhammad, Ekonomi ...., h.267. 
horizontal sampai memotong $\mathrm{TC}$ dan $\mathrm{TC}_{\mathrm{i}}$ pada sumbu Y. Selanjutnya membuat garis vertikal ke bawah sumbu $\mathrm{X}$ untuk masing-masing perpotongan antara garis horizontal dengan $\mathrm{TC}$ dan $\mathrm{TC}_{\mathrm{i}}$.

Dari analisis kurva yang menunjukkan biaya yang sama, jumlah produksi yang dihasikan sistem bagi hasil lebih efisien dibandingkan sistem bunga. Untuk total biaya yang sama (TC yang sama), jumlah produksi sistem bagi hasil ( $\left.\mathrm{Q}_{\mathrm{rs} / \mathrm{ps}}\right)$ selalu lebih besar dibandingkan jumlah produksi dengan sistem bunga $\left(Q_{i}\right)$ yang ditunjukkan dengan $Q_{r s / p s}>Q_{i}$. Jadi kriteria ini menunjukkan bahwa produksi dengan sistem bagi hasil lebih efisien dibandingkan menggunakan sistem bunga.

Jika diterapkan pada contoh kasus yang dibahas sebelumnya, maka grafiknya akan seperti berikut:

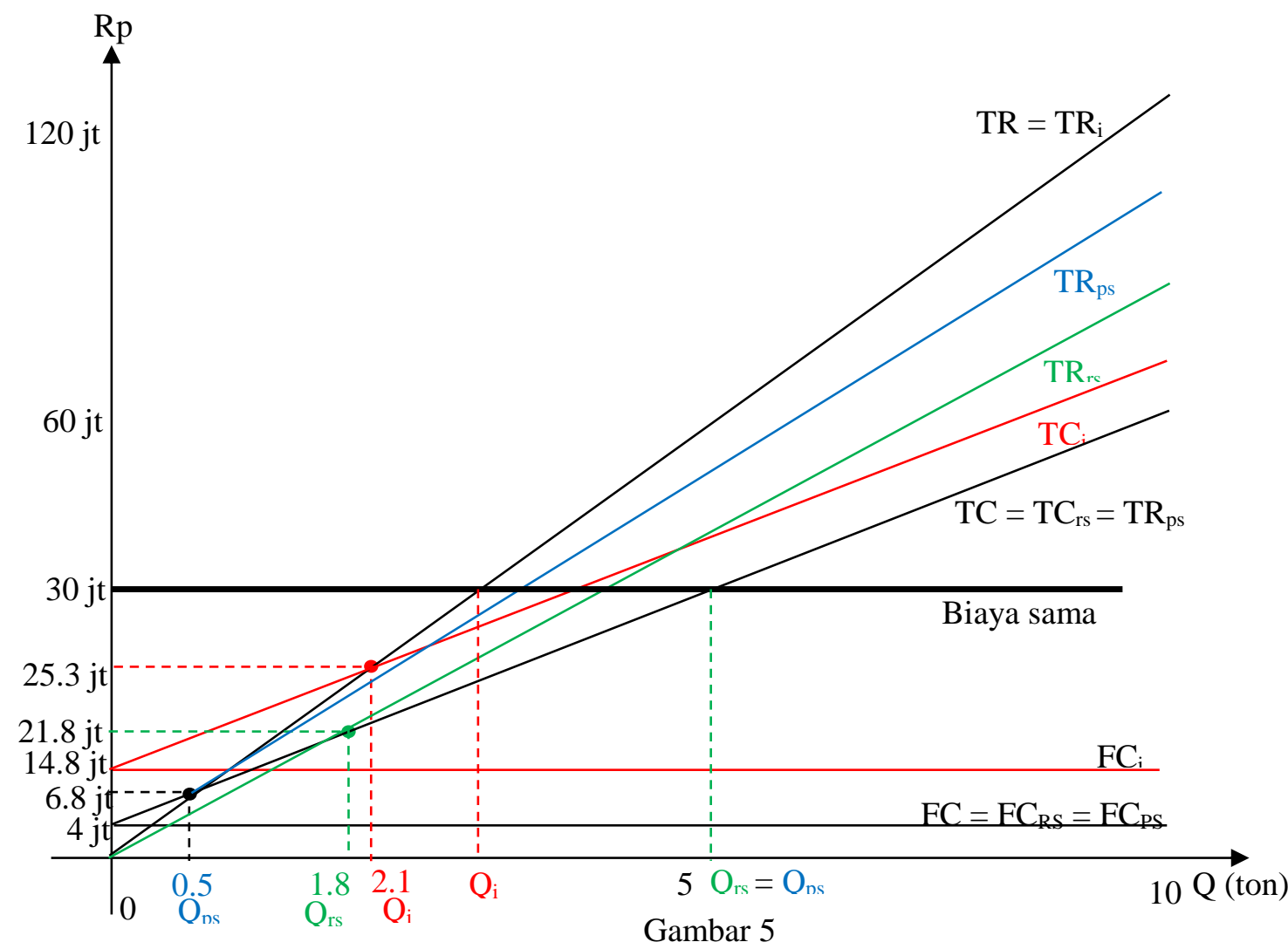


Pada grafik di atas terlihat jika biaya yang dikeluarkan sebesar Rp 30 juta maka dengan sistem bunga akan diperoleh produksi beras $\left(\mathrm{Q}_{\mathrm{i}}\right)<5$ ton, tetapi dengan jumlah biaya yang sama jika menggunakan sistem bagi hasil akan diperoleh produksi beras $\left(\mathrm{Q}_{\mathrm{rs} / \mathrm{ps}}\right)>5$ ton. Hal ini dapat dibuktikan dengan persamaan matematis:

\begin{tabular}{|l|}
\hline Sistem bunga \\
$\mathrm{TC}=(\mathrm{Q} \times \mathrm{AVC})+\mathrm{FC}$ \\
$30.0000 .000=5000 \mathrm{Q}+14.800 .000$ \\
$5.000 \mathrm{Q}=15.200 .000$ \\
$\mathrm{Q}=3.040 \mathrm{~kg}=3$ ton \\
\hline
\end{tabular}

$$
\begin{aligned}
& \text { Sistem bagi hasil } \\
& \mathrm{TC}=(\mathrm{Q} \times \mathrm{AVC})+\mathrm{FC} \\
& 30.0000 .000=5000 \mathrm{Q}+4.000 .000 \\
& 5.000 \mathrm{Q}=26.000 .000 \\
& \mathrm{Q}=5.200 \mathrm{~kg}=5,2 \text { ton }
\end{aligned}
$$

\section{Penutup}

Analisis biaya diperlukan untuk menentukan efisiensi produksi antara sistem bunga dengan sistem bagi hasil. Pada tingkat produksi dengan jumlah yang sama, biaya total yang digunakan pada sistem bunga lebih besar dibandingkan pada sistem bagi hasil. Hal ini berarti sistem bagi hasil lebih efisien. Pada jumlah biaya yang sama, tingkat produksi pada sistem bagi hasil lebih besar dibandingkan pada sistem bunga. Hal ini berarti sistem bagi hasil lebih efisien.

\section{Daftar Pustaka}

Putong, Iskandar. 2002. Ekonomi Mikro dan Makro (Edisi 2). Jakarta: Ghalia Indonesia.

Muhammad. 2016. Konsep Dasar Teori Ekonomi Mikro. Yogyakarta: BPFE.

Burhan, M. Umar. 2006. Sejarah Pemikiran Ekonomi Islam. Malang: Badan Penerbit Fakultas Ekonomi Universitas Brawijaya.

Karim, Adiwarman A. 2002. Ekonomi Mikro Islami. Jakarta: The International Institute of Islamic Thought. 
Masyhuri. 2007. Ekonomi Mikro. Malang : UIN-Malang Press.

Suryawati. tt. Teori Ekonomi Mikro. Yogyakarta : AMP YKPN.

Adiningsih, Sri dan Kadarusman, Y.B. 2008. Teori Ekonomi Mikro. Yogyakarta: BPFE-Yogyakarta. 